\title{
Woven-Fiber Microfiltration (WFMF) and Ultraviolet Light Emitting Diodes (UV LEDs) for Treating Wastewater and Septic Tank Effluent
}

\author{
Sara E. Beck ${ }^{1,2}, * \mathbb{B}$, Poonyanooch Suwan ${ }^{1}$, Thusitha Rathnayeke ${ }^{1}$, Thi Minh Hong Nguyen ${ }^{1,3} \mathbb{1}$, \\ Victor A. Huanambal-Sovero ${ }^{4}(\mathbb{})$, Boonmee Boonyapalanant ${ }^{1}$, Natalie M. Hull ${ }^{5,6} \mathbb{D}^{-}$and Thammarat Koottatep ${ }^{1}$
}

check for updates

Citation: Beck, S.E.; Suwan, P.; Rathnayeke, T.; Nguyen, T.M.H.; Huanambal-Sovero, V.A.; Boonyapalanant, B.; Hull, N.M.; Koottatep, T. Woven-Fiber Microfiltration (WFMF) and Ultraviolet Light Emitting Diodes (UV LEDs) for Treating Wastewater and Septic Tank Effluent. Water 2021, 13, 1564. https://doi.org/10.3390/ w13111564

Academic Editors: Simona Consoli and Giuseppe Luigi Cirelli

Received: 1 April 2021

Accepted: 27 May 2021

Published: 31 May 2021

Publisher's Note: MDPI stays neutral with regard to jurisdictional claims in published maps and institutional affiliations.

Copyright: (C) 2021 by the authors. Licensee MDPI, Basel, Switzerland. This article is an open access article distributed under the terms and conditions of the Creative Commons Attribution (CC BY) license (https:// creativecommons.org/licenses/by/ $4.0 /)$.
1 School of Environment, Resources, and Development, Asian Institute of Technology, 58 Moo 9, Km. 42, Paholyothin Highway, Khlong Luang, Pathum Thani 12120, Thailand; poonyanooch@ait.ac.th (P.S.); thusitha@ait.ac.th (T.R.); thiminhhong.nguyen@uq.edu.au (T.M.H.N.); boonmee@ait.ac.th (B.B.); thamarat@ait.ac.th (T.K.)

2 Department of Civil Engineering, University of British Columbia, Vancouver, BC V6T 1Z4, Canada

3 QAEHS-Queensland Alliance for Environmental Health Sciences, The University of Queensland, Brisbane, QLD 4102, Australia

4 Departamento de Ingeniería, Facultad de Ciencias y Filosofía, Universidad Peruana Cayetano Heredia, Lima 15102, Peru; victor.huanambal.s@upch.pe

5 Department of Civil, Environmental, and Geodetic Engineering, The Ohio State University, Columbus, OH 43210, USA; hull.305@osu.edu

6 Sustainability Institute, The Ohio State University, Columbus, OH 43210, USA

* Correspondence: sara.beck@ubc.ca

\begin{abstract}
Decentralized wastewater treatment systems enable wastewater to be treated at the source for cleaner discharge into the environment, protecting public health while allowing for reuse for agricultural and other purposes. This study, conducted in Thailand, investigated a decentralized wastewater treatment system incorporating a physical and photochemical process. Domestic wastewater from a university campus and conventional septic tank effluent from a small community were filtered through a woven-fiber microfiltration (WFMF) membrane as pretreatment for ultraviolet (UV) disinfection. In domestic wastewater, WFMF reduced TSS (by 79.8\%), turbidity (76.5\%), COD (38.5\%), and $\mathrm{NO}_{3}(41.4 \%)$, meeting Thailand irrigation standards for every parameter except BOD. In septic tank effluent, it did not meet Thailand irrigation standards, but reduced TSS (by 77.9\%), COD (37.6\%), and TKN (13.5\%). Bacteria (total coliform and Escherichia coli) and viruses (MS2 bacteriophage) passing through the membrane were disinfected by flow-through UV reactors containing either a low-pressure mercury lamp or light-emitting diodes (LEDs) emitting an average peak wavelength of $276 \mathrm{~nm}$. Despite challenging and variable water quality conditions $(2 \%<\mathrm{UVT}<88 \%)$, disinfection was predictable across water types and flow rates for both UV sources using combined variable modeling, which enabled us to estimate log inactivation of other microorganisms. Following UV disinfection, wastewater quality met the WHO standards for unrestricted irrigation.
\end{abstract}

Keywords: decentralized; domestic wastewater; septic tank effluent; woven membrane; UV validation; combined variable modelling; LMIC; MS2 bacteriophage

\section{Introduction}

By 2050, global water demand is projected to be $20-30 \%$ higher than current levels, given both population growth and socioeconomic development [1]. Agriculture accounts for the highest percentage of water withdrawals worldwide, contributing to roughly $70-85 \%$ of freshwater withdrawals in some developing economies [2]. This trend is predicted to continue for decades. Easing the burden on our freshwater resources requires increasing the use of reclaimed water, particularly for agriculture and irrigation; however, reclaimed water poses health risks to users [3]. 
The WHO/UNICEF Joint Monitoring Programme characterizes sanitation facilities into five categories: (1) open defecation, (2) unimproved services such as pit latrines, (3) limited or shared facilities, (4) "basic" sanitation services, and (5) safely managed facilities where the excreta are treated and safely disposed of [4]. Basic sanitation facilities include flush and pour-flush toilets, septic tanks, and improved pit latrines where the waste is collected but not safely managed beyond the toilet [4]. An estimated $29 \%$ of the global population ( 2.1 billion people) fall into this category [4]; of them, many live in the Asia and Pacific region, including Thailand. Thailand is one of the few countries in Southeast Asia with near complete coverage of basic sanitation nationwide; however, the waste is not safely managed, leading to a high prevalence of disease [5]. Only approximately $21 \%$ of human waste is treated at a municipal facility [4-6]. The remainder is often discharged into the environment or nearby neighborhoods, flowing directly into receiving waters, contaminating local water supplies and affecting public and environmental health.

Wastewater is one of the primary point source contaminants polluting freshwater and marine environments as well as shallow groundwater sources. Contaminated surface water contributes to disease burden and, as a result, adversely impacts the economy $[5,7]$. Public and private wells are susceptible to contamination by enteric pathogens, including viruses, bacteria, and protozoa [8], and septic tanks have been identified as a source of that contamination [9-11]. Enteric viruses have been detected in wells as far as $32 \mathrm{~m}$ from the septic tank source of fecal pollution, thus, contamination poses a significant threat in areas with on-site septic systems without appropriate treatment [12]. Thailand has recognized this serious environmental problem and identified a need for wastewater collection and treatment while encouraging decentralized treatment for households and buildings [6]. Decentralized wastewater treatment systems enable wastewater to be treated at the source for cleaner discharge into the environment, while allowing for potential reuse for agricultural and other purposes.

Membrane technology plays a substantial role in decentralized wastewater treatment and reuse [13,14]; however, membranes are relatively costly and require well-trained operation, making application at a household level challenging. Woven-fiber microfiltration (WFMF) membranes have recently been introduced as a cost-effective, robust, and easy-tooperate filtration method [15]. WFMF textiles have been successful for point-of-use water treatment when combined with disinfectants such as sodium hypochlorite, bromochlor, and silver nanoparticles [16,17]. In addition, fouling removal for WFMF, which is one of the most important maintenance requirements in membrane operation, is possible by removing a cake layer without required chemical addition [17]. Thus, WFMF membranes have proven effective in less populated areas and in decentralized systems $[18,19]$.

Ultraviolet (UV) light is frequently used for pathogen inactivation in water and wastewater treatment [20-22]. UV light effectively inactivates viruses, bacteria, and cysts by penetrating cell walls and damaging DNA or RNA without chemical addition. Traditional UV lamps are low-cost and accessible in developing economies, but contain toxic mercury vapor. UV LEDs are more expensive, but also mercury-free. They are significantly smaller, lighter, and more durable than traditional lamps, and require less power. In the Middle East, traditional UV lamps have been used for inactivating enteric pathogens remaining after treatment by constructed wetlands [23]. In the Mediterranean, UV LEDs were used to inactivate fecal bioindicators present after centralized wastewater treatment using activated sludge [24]. In our previous work in Southeast Asia, we investigated a household or building-scale UV LED reactor for disinfecting pretreated domestic wastewater for agriculture reuse [25]. In that study, the wastewater was pretreated with conventional slow-sand filtration and inclined settling, which was low-cost but high in footprint. In this study, we evaluated a system with a smaller footprint and shorter operating time.

This study evaluated a cost-effective, user-friendly, and relatively fast treatment process involving a woven-fiber microfiltration (WFMF) membrane to filter domestic wastewater followed by UV disinfection to disinfect the permeate. With an effective pore size of 1-3 $\mu \mathrm{m}$ [26], the WFMF was capable of removing Ascaris lumbricoides eggs (50 mm) 
and Giardia cysts $(10 \mu \mathrm{m})$, whereas bacteria $(1-2 \mu \mathrm{m})$, viruses, and Cryptosporidum oocysts $(3 \mu \mathrm{m})$, which are small enough to pass through the filter pores, were inactivated by exposure to UV light. Standard mercury lamps and UV LEDs were investigated. This work is targeted at developing and evaluating a water reuse process for addressing water scarcity and contamination in low to middle income areas. The objective was to determine if disinfected permeate could meet the Thailand standards for irrigation and WHO guidelines for building effluent water quality [27-29].

\section{Materials and Methods}

\subsection{Wastewater Sources}

This research evaluated a combined WFMF and UV LED system with two wastewater sources: domestic wastewater and conventional septic tank effluent. Domestic wastewater was collected from a collection tank at the Asian Institute of Technology (AIT) campus (Khlong Luang, Pathum Thani Province, Thailand) as in Nguyen et al. [25]. It was produced by a residential population of 2000-2500 along with a transient commercial and academic population, combining blackwater from toilets and greywater from kitchens and sinks. Conventional septic tank effluent was pumped from a septic tank serving a toilet used by 30-50 people/day (Phra Pradaeng, Samut Prakan Province, Thailand). For both wastewater sources, $200 \mathrm{~L}$ were collected and analyzed weekly for at least four weeks.

\subsection{Wastewater Quality Characterization}

Wastewater quality parameters were monitored weekly, following the Standard Methods for the Examination of Water and Wastewater [30]. These include $\mathrm{pH}$, temperature, electrical conductivity, total suspended solids (TSS), biological oxygen demand (BOD), chemical oxygen demand (COD), total Kjehdahl nitrogen (TKN), ammonia nitrogen $\left(\mathrm{NH}_{3}-\mathrm{N}\right)$, nitrate nitrogen $\left(\mathrm{NO}_{3}-\mathrm{N}\right)$, and total phosphorous (TP). Microbiological analysis also followed the Standard Methods for detecting fecal indicator bacteria, Escherichia coli, and total coliforms, which were measured as mean probable number (MPN) per $100 \mathrm{~mL}$ [30]. Ascaris lumbricoides ova were selected as an indicator of helminth eggs [31]. Regarding physicochemical parameters, removal efficiency $(R, \%)$ was calculated as $R=100 \times\left(C_{i n}-C_{\text {out }}\right) / C_{i n}$, where $\mathrm{C}_{\text {in }}$ and $\mathrm{C}_{\text {out }}$ represent the inlet and outlet concentrations to the WFMF system, respectively, which were collected at the same time. UV absorbance (UVA, $\mathrm{cm}^{-1}$ ) was measured using a Hitachi U-2900 spectrophotometer (Tokyo, Japan). UV transmittance (UVT, \%) for a given wavelength, $\lambda$, was calculated as $\mathrm{UVT}_{\lambda}=100 \times 10^{-\mathrm{a}(\lambda)}$, where $\mathrm{a}(\lambda)$ is the UVA at each wavelength.

\subsection{Woven-Fiber Microfiltration System}

The wastewater effluents were filtered through a woven-fiber microfiltration (WFMF) membrane system as a physical barrier to remove particles and suspended solids prior to photochemical disinfection with ultraviolet (UV) light. The polyester woven-fiber material was supplied by Dr. Lingam Pillay from Stellenbosch University. The material has a nominal pore size of 1-3 $\mu \mathrm{m}$ [26].

The flat sheet WFMF membranes were fabricated in the environmental engineering laboratory at Asian Institute of Technology, Thailand. The WFMF membrane module used in this study (Figure 1) was designed with five double-sided flat sheet woven-fiber textile modules $(21.0 \times 29.7 \mathrm{~cm})$, corresponding to a total surface area of $1 \mathrm{~m}^{2}$. Each membrane module contained a 3-layer structure of woven-fiber membranes and PVC spacer; the layers and the permeate flow collection channel were joined together with adhesive to the PVC frame. The membrane tank was fabricated with PVC materials to have a conical shape to help settle the accumulated sludge and remove solids. Total tank volume was $130 \mathrm{~L}$, with a sludge cone volume of $23.5 \mathrm{~L}$.

The system was operated in batch mode, in dead-end, outside-in configuration with the submerged membrane module operated by negative pressure as the driving force. The electrical control system was designed to have an automated operation. Suction 
pressure was created by changing the speed of a rotary-style peristaltic suction pump (Model 77200-60, Master Flex, Wertheim, Germany), shown as $P_{2}$ in Figure 1. A pressure transducer (Model 579225-010, Trafag, Bubikon, Switzerland) and data logger (Model-ELUSB-4, Lascar Electronics, Wiltshire, UK) were used to record pressure data. The peristaltic suction pump was connected to a timer (Omron twin timer- H3CR-F8) and operated with intermittent running intervals (OFF $1 \mathrm{~min}, \mathrm{ON} 6 \mathrm{~min}$ ). A level controller system (Omron $61 \mathrm{~F}-\mathrm{G}$ ) was introduced to the membrane tank to maintain a consistent water level inside the tank by connecting with the feed pump $\left(\mathrm{P}_{1}\right)$.

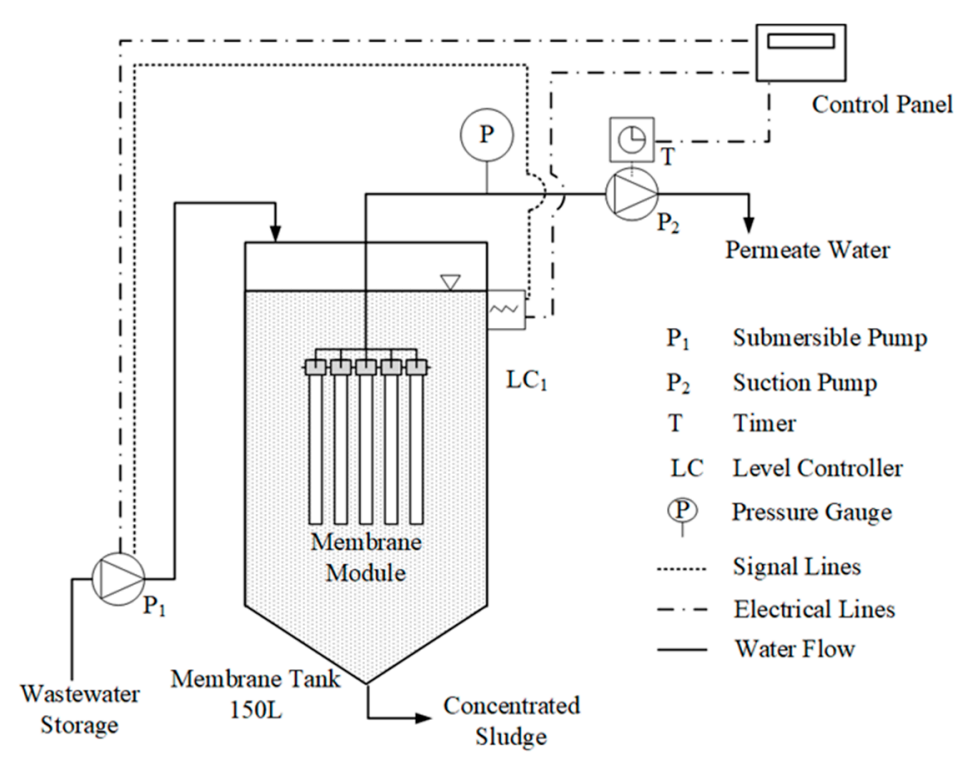

Figure 1. Schematic of the woven-fiber microfiltration (WFMF) system.

The system was operated continuously at $8 \mathrm{~L} / \mathrm{m}^{2} / \mathrm{h}$ with a goal to reduce the turbidity below $5 \mathrm{NTU}$ (nephelometric turbidity units) and to reduce the total suspended solids below $30 \mathrm{mg} / \mathrm{L}$ as pretreatment for UV disinfection [32-34]. The permeate water from the WFMF system was introduced to the UV reactors for disinfection.

Although cleaning was not necessary during these WFMF experiments, the membrane cleaning process is typically conducted when transmembrane pressure (TMP) reaches $-60 \mathrm{kPa}$. The process includes a physical, spray-brush method to remove colloids, followed by a chemical cleaning process for organic and inorganic fouling removal. Membranes are immersed in a solution of $0.5 \mathrm{M} \mathrm{NaOH}$ and $0.03 \% \mathrm{NaOCl}$ for $8 \mathrm{~h}$ to remove organic fouling constituents. Once the base cleaning is carried out, the membrane is immersed in a solution of $0.01 \%$ of $\mathrm{HCl}$ for $8 \mathrm{~h}$ to remove inorganic constituents prior to tap water cleaning and use.

\subsection{Flow-Through UV Reactors}

Approximately 25-30 L of WFMF permeate was collected for disinfection with one of two flow-through UV disinfection systems, a low-pressure (LP) UV lamp or UV LEDs, both of which were constructed in-house at the Asian Institute of Technology. The LP UV reactor (Figure 2) contained a $20 \mathrm{~W}$ mercury vapor lamp, emitting monochromatic UV irradiation at $254 \mathrm{~nm}$ (TOKIVA G20T8 by CCS SUCCESSPRODUCT Company Limited, Thailand), which was encased inside a welded stainless-steel casing with a small gasket. The reactor was $58.8 \mathrm{~cm}$ in length with an inner diameter of $4.6 \mathrm{~cm}$ surrounding the $2.5 \mathrm{~cm}$ diameter lamp for a maximum path length within the reactor of $1.05 \mathrm{~cm}$. The lamp was connected to a ballast with voltage adapter as shown (Figure 2), supplying a constant voltage of $58 \mathrm{~V}$ at $0.36 \mathrm{~mA}$. Water flowed outside the light source with a volume of $0.688 \mathrm{~L}$ up to the reactor's maximum flow rate of $1.8 \mathrm{~L} / \mathrm{min}$. 
The UV LED reactor (Figure 3) contained 4 UV LED arrays emitting polychromatic irradiation near $280 \mathrm{~nm}$ (TDS-UV280J16-C-A/H, TDS LIGHT Company Limited, China). Each array contained 16 diodes arranged in a $4 \times 4$ pattern and measuring $14 \times 14 \mathrm{~mm}$ in size. The arrays were mounted on four sides, forming a square outside of a cylindrical quartz sleeve $(1.8 \mathrm{~cm}$ diameter $\times 20 \mathrm{~cm}$ length). In contrast to the LP UV system, water flowing inside the sleeve $(0.051 \mathrm{~L})$ was irradiated by LEDs on the outside with a path length of $0.9 \mathrm{~cm}$ at flow rates up to $0.1 \mathrm{~L} / \mathrm{min}$. Together, the UV LED emission spectra (Figure 3) had an average peak of $276.2 \mathrm{~nm}$, a weighted average wavelength of $278.1 \mathrm{~nm}$, and an average full width at half maximum (FWHM) of $10.6 \mathrm{~nm}$. Emission spectra were measured at the National Institute of Metrology Thailand (NIMT) using a diode array spectroradiometer (CAS140CT-154) with non-optical density filter and cosine receptor probe (EOP-146, Instrument Systems, Germany). The arrays were wired in parallel at a current of $80 \mathrm{~mA}$ and a voltage of 21-24 DC.

The two UV light sources in this study were not meant for direct comparison, rather this was the state of their development at the time of experimentation (2016). Operating in the germicidal UV-B and UV-C range, both light sources induce damage to RNA and DNA through direct photolysis, causing microorganism inactivation [35]. Although fouling and scaling were not an issue during these experiments, fouling and scaling of UV systems is reversible through citric acid circulation [25].
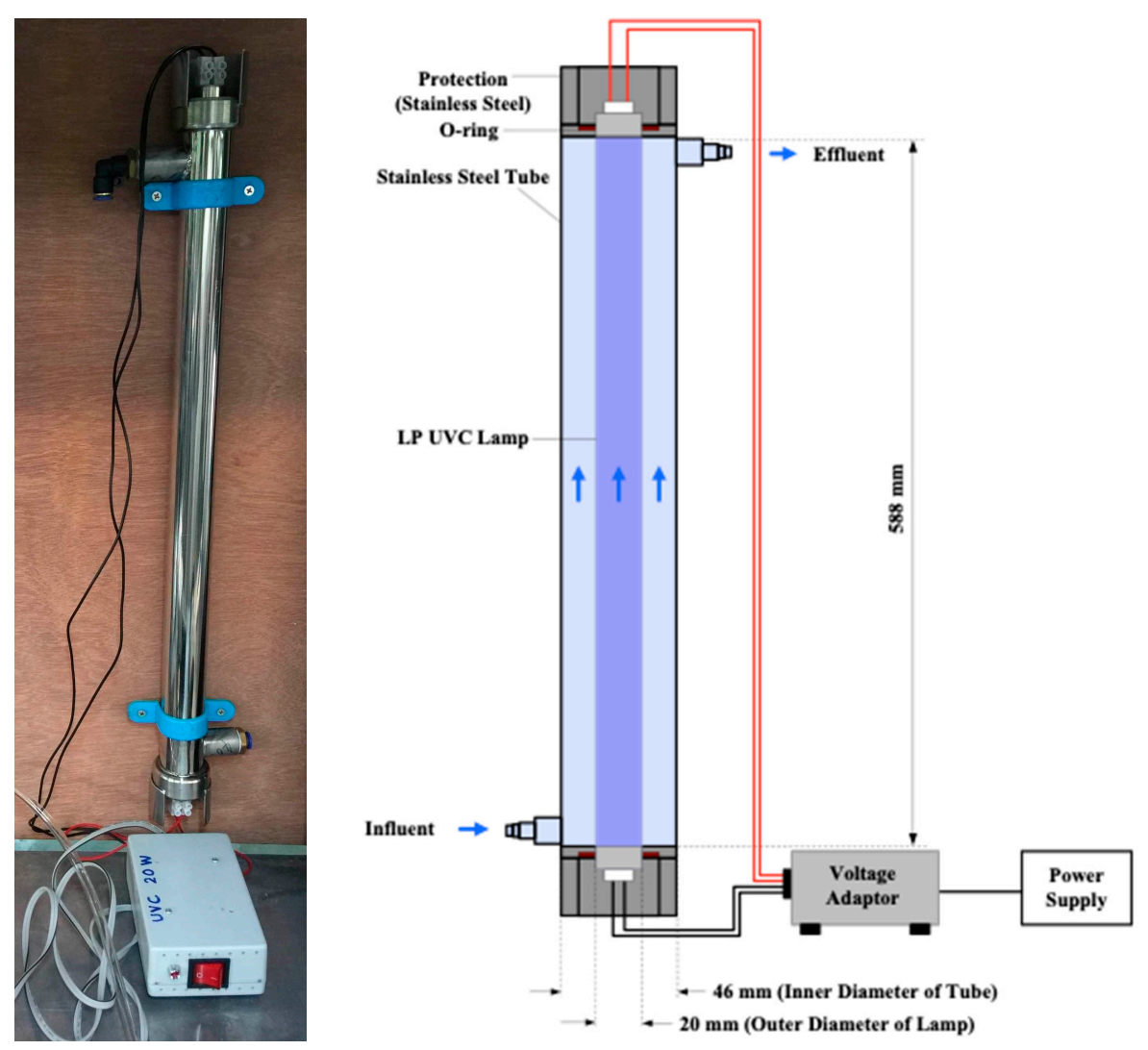

Figure 2. Photo and schematic of the flow-through low-pressure UV reactor constructed in-house in Thailand.

\subsection{UV Fluence Determination}

UV fluence $\left(\mathrm{mJ} / \mathrm{cm}^{2}\right)$, or dose, is calculated as the product of irradiance $\left(\mathrm{mW} / \mathrm{cm}^{2}\right)$ and time (s); therefore, the doses were changed by varying the exposure time for batch experiments, or by varying flow rate for flow-through experiments. The UV fluences applied by the flow-through reactors were calculated using biodosimetry with MS2 bacteriophage as described previously $[25,35,36]$. Bacteriophages such as MS2 are common indicators of 
fecal contamination [37]. Virus inactivation studies often use MS2 as a surrogate for enteric viruses, RNA viruses, and other pathogens to allow a comparison between conventional and emerging water and wastewater treatment technologies [38-40]. MS2 has been used in water reclamation studies and is frequently used for validating small-scale and large-scale UV reactors [36,41].

Although the wastewater and septic tank effluent contained background concentrations of 0 to $10^{2.2} \mathrm{PFU} / \mathrm{mL}$ MS2, additional bacteriophage was spiked into the WFMF filtration permeates at $10^{6}-10^{8} \mathrm{PFU} / \mathrm{mL}$ as a surrogate microorganism for the disinfection study. The MS2 bacteriophage (ATCC 15597-B1, American Type Culture Collection, Manassas, VA, USA) was propagated and enumerated with E. coli Famp (ATCC 700891) as the bacterial host, following the USEPA double agar layer (DAL) method [25,42] with experimental and analytical duplicates. Log inactivation of MS2 was calculated as the ratio of $\log _{10}$ concentration of MS2 in the water sample before and after UV irradiation.
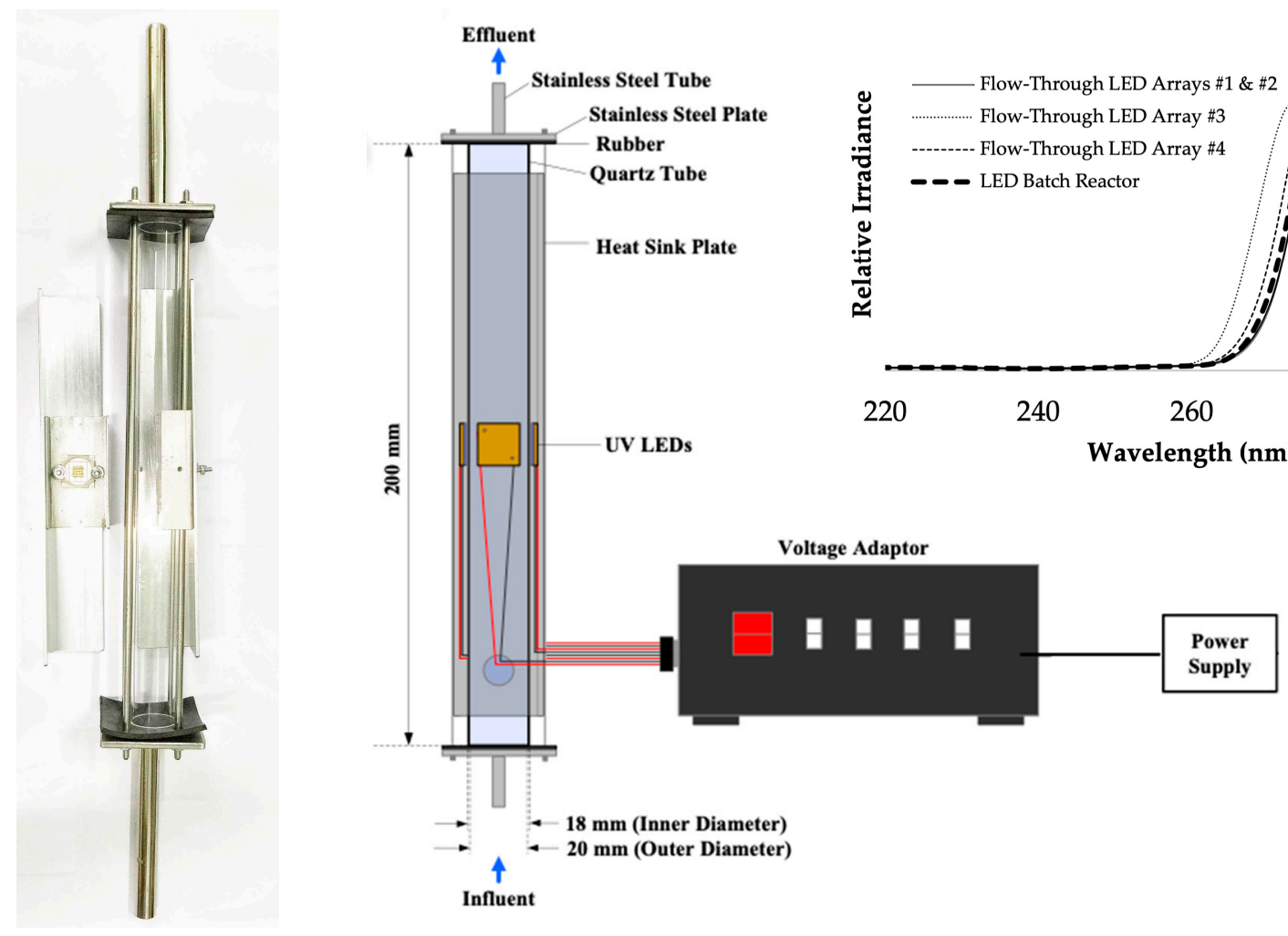

Figure 3. Photo, schematic, and emission spectra of the flow-through UV LED reactor constructed in Thailand.

For both flow-through reactors, the UV-induced log reduction of MS2 was measured at each flow rate for each water matrix tested. In parallel, quasi-collimated beam experiments were conducted with a batch reactor to determine the dose response of the microorganism in each wastewater matrix. Given the log reduction of MS2, the dose response curves were then used as a standard curve to back-calculate the reduction equivalent dose (RED) delivered by the flow-through reactors at each flow rate. Multiple flow rates were used for each experiment, corresponding to multiple UV doses. To evaluate the disinfection performance of the UV LEDs and the LP UV lamp for the flow-through reactors, the same wastewaters and septic tank samples spiked with MS2 were used for the batch tests in continuously stirred $5 \mathrm{~mL}$ samples (6 $\mathrm{mm}$ depth). Batch experiments with the UV LED batch reactor were conducted in parallel with experiments involving the flow-through UV LED reactor; batch experiments with the LP UV reactor were conducted in parallel with experiments using the flow-through LP UV reactor. 
UV LED batch reactor tests incorporated the batch reactor described previously [25] with a peak wavelength emission at $277 \mathrm{~nm}$ and a full width at half maximum (FWHM) of $10 \mathrm{~nm}$. As shown in Figure 3, the spectral emission of the batch reactor was exactly aligned with two of the arrays in the flow-through reactor and deviated from the other two arrays by approximately $1 \mathrm{~nm}$ and $3 \mathrm{~nm}$ at peak wavelength. This UV LED batch reactor was fully characterized for our previous study; the average irradiance across the surface of the water sample was determined using biodosimetry with MS2 as described previously [25]. Briefly, the published dose response of MS2 (suspended in phosphate buffered saline, PBS) to UV LEDs with the same wavelength emission (peak $=276.6 \mathrm{~nm}$; $\mathrm{FWHM}=9.8 \mathrm{~nm}$, inactivation rate constant $\mathrm{k}_{\mathrm{D}}=0.052 \mathrm{~cm}^{2} / \mathrm{mJ}$ ) was used to back-calculate the average irradiance across the surface of the water sample $[25,43]$. The average UV LED irradiance across the surface of each water sample measured through biodosimetry was $0.208 \mathrm{~mW} / \mathrm{cm}^{2} \pm 0.013$ (sample size, $n=3$ ). This value was then confirmed by off-site radiometry at the National Institute of Metrology Thailand $\left(0.212 \mathrm{~mW} / \mathrm{cm}^{2}\right)$ after adjusting for the Petri factor (0.876), reflection factor, sensor factor, and divergence factor [36]. Petri factor was sufficient over a coefficient of variation in this scenario because the irradiance peaked at the center of the dish (Figure S1) [44]. The value for average irradiance across the surface of the water sample was then used together with the water factor and the DNA absorbance spectrum to calculate the average germicidal irradiance throughout each water sample, as is conventional for polychromatic UV systems [45].

Similarly, for the low-pressure (LP) UV lamp, the published dose response of MS2 (suspended in PBS) to LP UV $\left(\mathrm{k}_{\mathrm{D}}=0.052 \mathrm{~cm}^{2} / \mathrm{mJ}\right)$ was used to back-calculate the average irradiance from the LP UV lamp across the surface of the water sample [21]. The average LP UV irradiance across the surface of the water sample measured through biodosimetry was $2.437 \mathrm{~mW} / \mathrm{cm}^{2} \pm 0.044(n=3)$. This was confirmed by off-site radiometry at NIMT $\left(2.442 \mathrm{~mW} / \mathrm{cm}^{2}\right)$. The average irradiance across the surface of the water sample was then used with the water factor to calculate the average irradiance throughout each sample.

The flow-through UV LED reactor was also validated by varying UV transmission (UVT) using coffee as recommended previously [36,41,46]. MS2 experiments therefore involved MS2 suspended in PBS, wastewater or septic tank effluent, or coffee to vary the UVT.

\subsection{Statistical Analysis}

All experiments were conducted multiple times with analytical duplicates or triplicates. Paired $t$-tests were conducted for evaluating the statistically significant differences between influent and effluent data of AIT wastewater and conventional septic tank effluent treated by WFMF.

\subsection{Combined Variable Approach to RED and Log Inactivation Modelling}

Reduction equivalent dose (RED) and log inactivation were modeled for a single challenge microorganism based on the combined variable approach presented by Wright et al. [47] and Hull et al. [48] and described in Equation (1):

$$
R E D \text { or } \log I=10^{a} \times U V A^{b} \times\left(\frac{S / S_{0}}{Q}\right)^{c+d \times U V A+e \times U V A^{2}}
$$

where UVA is the UV absorbance at 254 or $276 \mathrm{~nm}$ or the UVA weighted by relative lamp emission (RLE), as was the case with the polychromatic UV LEDs. $S / S_{0}$ is the ratio of measured UV intensity $(S)$ over UV intensity for new lamps $\left(S_{0}\right)$, which was assumed to equal 1 in these experiments. $Q$ is the volumetric flow rate $(\mathrm{L} / \mathrm{min})$. Empirical coefficients (a-e) were determined in R v. 4.0.3 and RStudio v. 1.4 .1103 by minimizing the sum of the squares of the difference between the measured and predicted values using the GaussNewton method for nonlinear least squares regression. The empirical coefficients (a-e) were determined to be statistically significant based on their $p$-value $(p<0.05)$. Coefficients that were not statistically significant were removed (i.e., set equal to zero) from the model in 
a stepwise fashion, starting with the coefficient with the highest $p$-value [47]. The final log inactivation and RED models included only statistically significant coefficients. Following the findings from Hull et al. [48], log inactivation by UV LEDs was modeled as a function of RLE absorbance and flow rate. LP UV log inactivation was modeled as a function of $\mathrm{UVA}_{254}$ and flow rate.

\section{Results and Discussion}

\subsection{WFMF Membrane System Performance}

Table 1 presents the quality of the wastewater and septic tank effluent used in these experiments before and after the WFMF membrane filtration pretreatment. WFMF removal performance for various parameters in the AIT campus domestic wastewater and septic effluent are given in Figure 4. Compared to the literature, for a typical composition of lowstrength untreated domestic wastewater in the United States, AIT domestic wastewater, which comprises blackwater and greywater, is more dilute (by approximately half) for solids, BOD, and COD, but has almost double the nutrient content [49]. However, these values are in line with other wastewater systems in Southeast Asia [50]. Parameters from the septic tank effluent from Phra Pradaeng, including COD, BOD, and TKN, are also on par for conventional septic tanks in the region [50,51].

Table 1. Characteristics of AIT wastewater and conventional septic tank effluent before (raw) and after the WFMF pretreatment (permeate). Data presented as average \pm SD with sample size $n$. Parameters marked with a "-" indicate data that was not collected or lost.

\begin{tabular}{|c|c|c|c|c|c|}
\hline $\begin{array}{l}\text { Parameters } \\
\text { (Units) }\end{array}$ & Analysis Method & Raw Wastewater & $\begin{array}{c}\text { Wastewater } \\
\text { WFMF Permeate }\end{array}$ & $\begin{array}{l}\text { Raw Septic } \\
\text { Tank Effluent }\end{array}$ & $\begin{array}{c}\text { Septic Tank } \\
\text { WFMF Permeate }\end{array}$ \\
\hline $\mathrm{pH}$ & 4500B-H+ & $\begin{array}{c}7.29 \pm 0.31 \\
n=15\end{array}$ & $\begin{array}{c}7.46 \pm 0.48 \\
n=15\end{array}$ & $\begin{array}{c}7.32 \pm 0.39 \\
n=14\end{array}$ & - \\
\hline Temp $\left({ }^{\circ} \mathrm{C}\right)$ & - & $\begin{array}{c}29.0 \pm 4.1 \\
n=15\end{array}$ & $\begin{array}{c}29.3 \pm 3.7 \\
n=15\end{array}$ & $\begin{array}{c}29.4 \pm 2.7 \\
n=14\end{array}$ & - \\
\hline $\begin{array}{l}\text { Conductivity } \\
\left(\mu \mathrm{S} / \mathrm{cm}^{2}\right)\end{array}$ & 2510B & $\begin{array}{c}724 \pm 49 \\
n=13\end{array}$ & $\begin{array}{c}728 \pm 54 \\
n=13\end{array}$ & $\begin{array}{c}2795 \pm 236 \\
n=14\end{array}$ & - \\
\hline TSS (mg/L) & $2540 \mathrm{D}$ & $\begin{array}{c}65.7 \pm 67 \\
n=15\end{array}$ & $\begin{array}{c}8.6 \pm 4 \\
n=15\end{array}$ & $\begin{array}{c}128.8 \pm 33 \\
n=21\end{array}$ & $\begin{array}{c}56.5 \pm 31 \\
\quad n=4\end{array}$ \\
\hline Turbidity (NTU) & $2130 \mathrm{~B}$ & $\begin{array}{c}34.4 \pm 22 \\
n=15\end{array}$ & $\begin{array}{c}5.9 \pm 6.0 \\
n=14\end{array}$ & - & - \\
\hline $\mathrm{BOD}(\mathrm{mg} / \mathrm{L})$ & 5210B & $\begin{aligned} 51.9 & \pm 27.1 \\
n & =7\end{aligned}$ & $\begin{aligned} 31.3 & \pm 26.9 \\
n & =7\end{aligned}$ & $\begin{array}{c}302.8 \pm 124 \\
n=9\end{array}$ & - \\
\hline $\mathrm{COD}(\mathrm{mg} / \mathrm{L})$ & $5220 \mathrm{C}$ & $\begin{array}{c}96.2 \pm 41 \\
n=16\end{array}$ & $\begin{array}{c}58.3 \pm 32 \\
n=16\end{array}$ & $\begin{array}{c}510.6 \pm 167 \\
n=19\end{array}$ & $\begin{array}{c}242.8 \pm 77 \\
\quad n=4\end{array}$ \\
\hline $\mathrm{TKN}$ (mg/L) & $4500-\mathrm{N}_{\text {org }} \mathrm{C}$ & $\begin{array}{c}49.5 \pm 32 \\
n=8\end{array}$ & $\begin{array}{c}30.0 \pm 3 \\
n=8\end{array}$ & $\begin{array}{c}264.8 \pm 20 \\
n=20\end{array}$ & $\begin{array}{c}240.6 \pm 8 \\
n=2\end{array}$ \\
\hline $\mathrm{NH}_{3}-\mathrm{N}(\mathrm{mg} / \mathrm{L})$ & 4500-NH3 C & $\begin{array}{c}24.9 \pm 8.7 \\
n=9\end{array}$ & $\begin{array}{c}24.6 \pm 7.9 \\
n=9\end{array}$ & $\begin{array}{c}257.0 \pm 53 \\
n=20\end{array}$ & $\begin{array}{c}191.2 \pm 63 \\
n=4\end{array}$ \\
\hline $\mathrm{NO}_{3}-\mathrm{N}(\mathrm{mg} / \mathrm{L})$ & 8039-HR & $\begin{array}{c}3.9 \pm 2.8 \\
n=7\end{array}$ & $\begin{array}{c}1.7 \pm 1.4 \\
n=7\end{array}$ & $\begin{array}{c}5.4 \pm 3.2 \\
n=2\end{array}$ & $\begin{array}{c}3.4 \pm 2.4 \\
n=2\end{array}$ \\
\hline $\mathrm{TP}(\mathrm{mg} / \mathrm{L})$ & $4500 \mathrm{P}$ & $\begin{array}{c}24.4 \pm 28 \\
n=9\end{array}$ & $\begin{array}{c}18.0 \pm 19 \\
n=9\end{array}$ & $\begin{array}{c}368.7 \pm 105 \\
n=2\end{array}$ & $\begin{array}{c}320.8 \pm 83 \\
\quad n=2\end{array}$ \\
\hline $\begin{array}{c}\text { A. lumbricoides ova } \\
(\mathrm{eggs} / \mathrm{L})\end{array}$ & {$[31]$} & $\begin{array}{c}0 \\
n=5\end{array}$ & $\begin{array}{c}0 \\
n=5\end{array}$ & - & - \\
\hline
\end{tabular}


Table 1. Cont.

\begin{tabular}{|c|c|c|c|c|c|}
\hline $\begin{array}{l}\text { Parameters } \\
\text { (Units) }\end{array}$ & Analysis Method & Raw Wastewater & $\begin{array}{c}\text { Wastewater } \\
\text { WFMF Permeate }\end{array}$ & $\begin{array}{c}\text { Raw Septic } \\
\text { Tank Effluent }\end{array}$ & $\begin{array}{c}\text { Septic Tank } \\
\text { WFMF Permeate }\end{array}$ \\
\hline $\begin{array}{l}\text { Total coliforms } \\
\text { (MPN/100 mL) }\end{array}$ & $9221 C$ & $\begin{array}{c}1.0 \times 10^{6} \\
\pm 2.6 \times 10^{6} \\
n=9\end{array}$ & $\begin{array}{c}3.3 \times 10^{5} \\
\pm 5.1 \times 10^{5} \\
n=9\end{array}$ & $\begin{array}{c}1.3 \times 10^{7} \\
\pm 2.7 \times 10^{7} \\
n=17\end{array}$ & $\begin{array}{c}1.6 \times 10^{6} \\
\pm 1.6 \times 10^{6} \\
n=2\end{array}$ \\
\hline $\begin{array}{c}\text { E. coli } \\
\text { (MPN/100 mL) }\end{array}$ & $9221 \mathrm{~F}$ & $\begin{array}{c}3.2 \times 10^{5} \\
\pm 7.0 \times 10^{5} \\
n=9\end{array}$ & $\begin{array}{c}1.5 \times 10^{5} \\
\pm 1.5 \times 10^{5} \\
n=9\end{array}$ & $\begin{array}{c}2.8 \times 10^{6} \\
\pm 2.7 \times 10^{6} \\
n=17\end{array}$ & $\begin{array}{c}3.5 \times 10^{5} \\
\pm 5.5 \times 10^{3} \\
n=2\end{array}$ \\
\hline $\begin{array}{l}\text { MS2 coliphage } \\
(\mathrm{PFU} / \mathrm{mL})\end{array}$ & USEPA 1602 & $\begin{array}{c}16 \pm 44 \\
n=11\end{array}$ & $\begin{array}{l}7 \pm 17 \\
n=11\end{array}$ & $\begin{array}{c}19 \pm 13 \\
n=4\end{array}$ & $\begin{array}{c}19 \pm 25 \\
n=4\end{array}$ \\
\hline $\mathrm{UVT}_{254}(\%)$ & & $\begin{array}{c}33.1 \pm 15 \\
n=14\end{array}$ & $\begin{array}{c}52.5 \pm 14 \\
n=18\end{array}$ & $\begin{array}{c}3.2 \pm 3.1 \\
n=3\end{array}$ & $\begin{aligned} 3.5 & \pm 1.7 \\
n & =4\end{aligned}$ \\
\hline $\mathrm{UVT}_{280}(\%)$ & & $\begin{array}{c}44.9 \pm 12 \\
n=3\end{array}$ & $\begin{array}{c}57.3 \pm 17 \\
n=8\end{array}$ & $\begin{array}{c}6.0 \pm 5.1 \\
n=3\end{array}$ & $\begin{array}{c}6.1 \pm 2.9 \\
n=4\end{array}$ \\
\hline
\end{tabular}

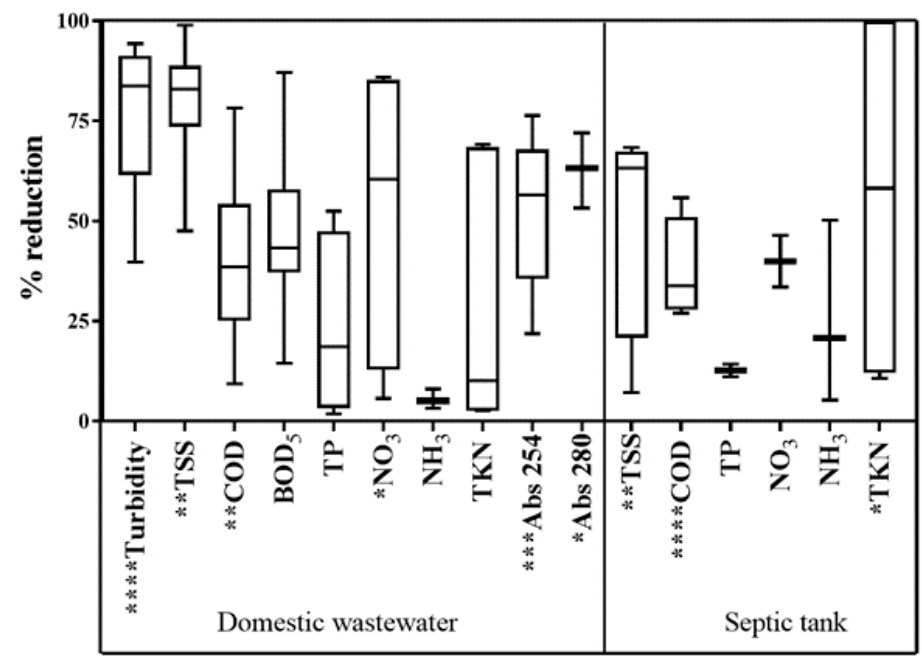

Figure 4. Box plots of WFMF removal efficiencies for treatment of AIT domestic wastewater and conventional septic tank effluent. Removal calculations included only influent and effluent data collected on the same day. Boxes and whiskers represent median and minimum to maximum values as well as 25 th-75th percentiles. ${ }^{* * *} p<0.0001,{ }^{* * *} p<0.001,{ }^{* *} p<0.01,{ }^{*} p \leq 0.05$, no asterisk means no significant difference between influent and effluent data.

\subsubsection{Domestic Wastewater}

Overall, the WFMF performed well with particle removal and acted as an efficient pretreatment unit for UV treatment of domestic wastewater, as shown in Table 2. Its primary drawback was not meeting irrigation guidelines for BOD set by the Thai Pollution Control Department [27]. The WFMF process did not cause a significant difference in $\mathrm{pH}$, temperature, or conductivity. The system, which had a pore size of $1-3 \mu \mathrm{m}$, separated the total suspended solid fraction, preventing most of the suspended solids content from passing through the membrane, resulting in a clearer permeate with fewer particles. For domestic wastewater, the WFMF reduced total suspended solid particles by $79.8 \%( \pm 13.9)$. This agreed well with a previous study on textile filters for wastewater treatment, which showed a suspended solids removal rate of $71 \%$ [52]. For domestic wastewater, the WFMF system generated product water quality with an average TSS of $8.6 \mathrm{mg} / \mathrm{L}$, which accommodates the effluent quality limit of $30 \mathrm{mg} / \mathrm{L}$ for irrigation systems in Thailand (Table 2, [27,28]). For all 15 samples tested, the TSS limits of product water fell below $30 \mathrm{mg} / \mathrm{L}$, which was also 
the suggested guideline for water reuse for processed food or non-food crops suggested by the USEPA (Table 2, [53]). Suspended solids removal was one of the primary objectives of the WFMF as pretreatment for UV disinfection and potential reuse applications.

Table 2. Characteristics of WFMF permeate compared to existing guidelines for water reuse.

\begin{tabular}{|c|c|c|c|c|c|}
\hline \multirow[b]{2}{*}{$\begin{array}{l}\text { Parameters } \\
\text { (Units) }\end{array}$} & \multicolumn{2}{|c|}{ This Study } & \multicolumn{2}{|c|}{ Guidelines } & \multirow[b]{2}{*}{$\begin{array}{c}\text { USEPA }^{3} \\
\text { Processed Food or } \\
\text { Non-Food Crops }\end{array}$} \\
\hline & $\begin{array}{c}\text { Wastewater } \\
\text { WFMF Effluent }\end{array}$ & $\begin{array}{c}\text { Septic Tank } \\
\text { WFMF Effluent }\end{array}$ & $\begin{array}{l}\text { Thailand } \\
\text { Irrigation } \\
\text { Standard }{ }^{1}\end{array}$ & $\begin{array}{c}\text { WHO } \\
\text { Unrestricted } \\
\text { Irrigation }^{2}\end{array}$ & \\
\hline $\mathrm{pH}$ & 7.5 & - & $6.5-8.5$ & & $6.0-9.0$ \\
\hline $\begin{array}{l}\text { Conductivity } \\
(\mu \mathrm{mol} / \mathrm{cm})\end{array}$ & 700 & - & $\leq 2000$ & & \\
\hline $\begin{array}{l}\text { Turbidity } \\
\text { (NTU) }\end{array}$ & 5.9 & - & - & & $\leq 2$ \\
\hline $\begin{array}{c}\text { TSS } \\
(\mathrm{mg} / \mathrm{L})\end{array}$ & 8.6 & 56.5 & $\leq 30$ & & $\leq 30$ \\
\hline $\begin{array}{c}\text { BOD } \\
(\mathrm{mg} / \mathrm{L})\end{array}$ & 31.3 & - & $\leq 20$ & & $\leq 30$ \\
\hline $\begin{array}{c}\mathrm{COD} \\
(\mathrm{mg} / \mathrm{L})\end{array}$ & 58.3 & 242.8 & $\leq 100$ & & \\
\hline $\begin{array}{c}\text { TKN } \\
(\mathrm{mg} / \mathrm{L})\end{array}$ & 30.0 & 240.6 & $\leq 35$ & & \\
\hline $\begin{array}{c}\mathrm{TP} \\
(\mathrm{mg} / \mathrm{L})\end{array}$ & 18.0 & 320.8 & - & & \\
\hline $\begin{array}{c}\mathrm{FC} \\
(\mathrm{CFU} / 100 \mathrm{~mL})\end{array}$ & & & - & $\leq 1000$ & $\leq 200$ \\
\hline $\begin{array}{l}\text { Total coliforms } \\
\text { (MPN/100 mL) }\end{array}$ & $1.0 \times 10^{6}$ & $1.1 \times 10^{6}$ & & & \\
\hline $\begin{array}{l}\text { Helminth eggs } \\
(\text { eggs/L) }\end{array}$ & 0 & - & & $\leq 1$ & \\
\hline
\end{tabular}

\footnotetext{
${ }^{1}[27,28] ;{ }^{2}[29] ;{ }^{3}[53]$.
}

As solid particles were retained by the WFMF system, the turbidity of the domestic wastewater was reduced by an average of $76.5 \%( \pm 26.9)$. Turbidity can have a significant effect on light-based disinfection; therefore, removal is necessary for UV pretreatment. Domestic wastewater filtered through the WFMF reached turbidities as low as 1.6 NTU with an average of 5.9 NTU. Although this value was higher than our goal of 5 NTU, it was still within the range of turbidities for UV inactivation of wastewater [32,54]. Similar studies of WFMF treatment of contaminated surface water reached turbidities of 1.0 NTU [17,54].

For domestic wastewater, the WFMF reduced COD and BOD levels by an average of $38.5 \%( \pm 17.3)$ and $47.8 \%( \pm 22.6)$, respectively, through the filtration process. Considering TSS removal efficiencies, showing that solids were mostly retained in the membrane, it was presumed that COD transferring through was predominantly soluble. The product water contained an average COD of $58.3 \mathrm{mg} / \mathrm{L}$, which falls under the $100 \mathrm{mg} / \mathrm{L}$ limit required by Thailand for irrigation (Table 2) $[27,28]$. BOD removal, however, did not meet the irrigation standards, with an average permeate quality of $31.3 \mathrm{mg} / \mathrm{L}$, which was higher than the required Thailand irrigation and USEPA processed food crop limits of $20 \mathrm{mg} / \mathrm{L}$ and $30 \mathrm{mg} / \mathrm{L}$, respectively (Table 2). This highlights the need for additional biological treatment of the wastewater. 
Total Kjeldahl nitrogen (TKN) was not reduced significantly; however, it maintained a permeate concentration of $30.0 \mathrm{mg} / \mathrm{L}$, which meets the Thailand effluent quality standards of $35 \mathrm{mg} / \mathrm{L}$ (Table 2). Ammonia nitrogen and total phosphorus were also not reduced significantly; however, nitrate nitrogen was reduced by an average of $41.4 \%( \pm 40.5)$. Previous studies involving WFMF membrane bioreactors showed statistically significant reduction of ammonia nitrogen, nitrite nitrogen, phosphate, and other nutrients; however, those studies involved biological membrane growth in which the biomass performed a nitrification step, whereas the WFMF in this study was primarily a physical removal process [26,48]. $\mathrm{UVT}_{254}$ improved from an average of $33.1 \%( \pm 15)$ to an average of $52.5 \%$ $( \pm 14)$ after WFMF filtration. Similarly, $\mathrm{UVT}_{280}$ improved from an average of $44.9 \%( \pm 12)$ to $57.3 \%( \pm 17)$. UVT spectra of treated permeates are given in Figure 5.

From a microbiological perspective, the WFMF was not effective at removing pathogens or indicator organisms, hence the need for UV disinfection. Ascaris lumbricoides ova, which measure 40-75 microns in size [55] would have been filtered out by the 1-3 micron pore size; however, they were not detected in the WFMF influent due to prior settling. The WFMF did not cause a significant reduction in total coliforms or E. coli, which was surprising compared to two previous studies where removal of $E$. coli from natural or synthetic surface water for noncoated woven-fiber membranes was found to be 84-99.8\% [16,17]. Those studies had higher turbidity in the influent, which could have caused a thicker cake layer formation, improving size exclusion and reducing bacteria.

MS2 bacteriophage was only present in small amounts in the influent, and its removal was also not statistically significant. A study on gravity-driven membranes indicated that biofilm growth on the membrane would have contributed an extra $2.0+\log$ removal of MS2 [56].

\subsubsection{Septic Tank Effluent}

As a pretreatment for UV, the WFMF also performed well for particle removal from the septic tank effluent, but the permeate wastewater quality did not meet the Thailand irrigation standard for any of the parameters (Table 2). When analyzing the WFMF removal performance for treating septic tank effluent, TSS was reduced by an average of $77.9 \%( \pm 13.3)$ to an average concentration of $56.5 \mathrm{mg} / \mathrm{L}$, above the irrigation standard requirement of $30 \mathrm{mg} / \mathrm{L}$ (Table 2). The WFMF treatment achieved a COD removal of 37.6\% $( \pm 12.8)$ in the septic tank effluent to a concentration of $242.8 \mathrm{mg} / \mathrm{L}$, above the required $100 \mathrm{mg} / \mathrm{L}$ limit. These results are similar to a study that characterized woven-fiber flat sheet membrane fouling in a membrane-based septic tank and resulted in 50-60\% TSS and 50-65\% COD removal [19].

Total Kjeldahl nitrogen (TKN) was reduced by $13.5 \%( \pm 4.0)$ to $240.6 \mathrm{mg} / \mathrm{L}$; however, this was still well above the Thailand effluent quality standards of $35 \mathrm{mg} / \mathrm{L}$ (Table 2). This treatment process was operated as a physical process and not a biological one; therefore, high reduction in nutrients was not expected. Ammonia nitrogen, nitrate nitrogen, and total phosphorus all showed reductions that were not statistically significant. For these parameters, the low sample sizes may have contributed to the insignificance. The primary goal of the WFMF was to remove suspended solids and improve the UVT for enhanced disinfection. Nevertheless, UVT was improved more for domestic wastewater; and was not improved with statistical significance for septic tank effluent. It is believed that this was due to dissolved humic acids present in the septic effluent, which were too small to be removed by the WFMF. UVT spectra of the treated permeates are given in Figure 5.

The WFMF system achieved $85.8 \%$ reduction of total coliform and $90.6 \%$ reduction of $E$. coli rates with the septic tank effluent water prior to the UV disinfection process. However, with a small sample size, these values were not statistically significant. As with domestic wastewater, MS2 bacteriophage was present in small amounts in the influent, and its removal was also not statistically significant. 


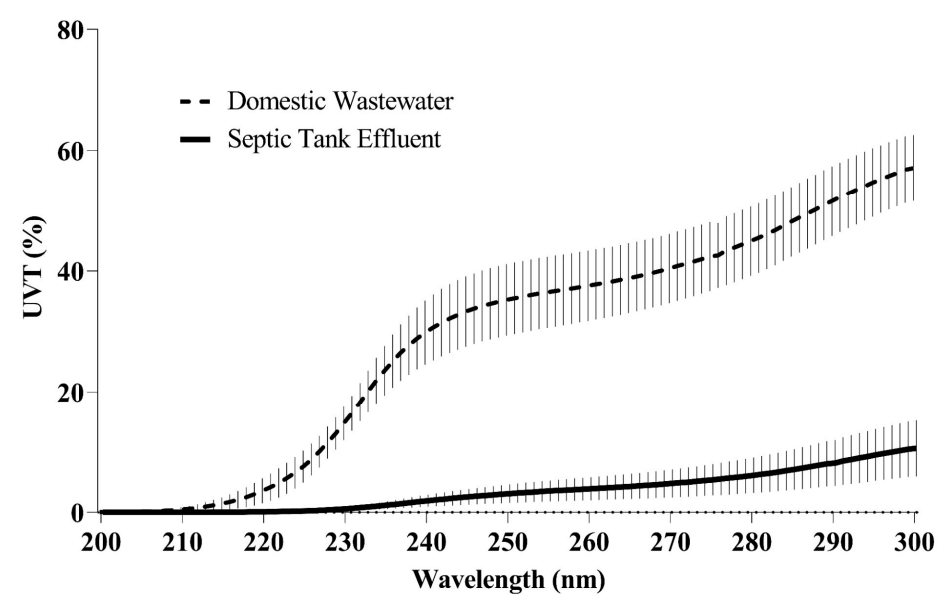

Figure 5. UV transmittance spectra of wastewater and septic tank from the WFMF permeate prior to UV exposure. Data represents average plus standard deviation.

\subsection{UV Disinfection System Performance}

The primary purpose of the LP UV and UV LED reactors was to disinfect bacteria, viruses, and protozoan pathogens remaining in the domestic wastewater and septic tank permeate.

\section{UV Dose Response Curves}

Results from the batch reactor experiments using LP UV and UV LEDs to disinfect treated domestic wastewater and septic tank effluent are given in Figure 6. These dose response curves show that the experiments were repeatable across a wide range of UVT values. These curves were used to determine the reduction equivalent dose, RED, in the flow-through reactors, given the MS2 log reduction at a specific flow rate, through biodosimetry. The dose response did not exhibit linear inactivation kinetics as in our previous study of UV LED inactivation of treated wastewater effluent; however, the wastewater in this study had higher TSS and turbidity values [25]. Suspended particles shield microorganisms from inactivation in a phenomenon called tailing, which invalidates the first-order kinetics model $[32,36,57]$. The results from wastewater disinfection match the literature, with 2-log inactivation occurring at a UV dose of $33.3 \mathrm{~mJ} / \mathrm{cm}^{2}$ for the LP UV source and $42.6 \mathrm{~mJ} / \mathrm{cm}^{2}$ for the LED/276 nm source [42]. The LP UV results fall within the National Water Research Institute (NWRI) Guidelines for Drinking Water and Water Reuse. LED results are not yet included in the NWRI guidelines [40]. The results for MS2 inactivation in the septic tank effluent; however, are lower than the NWRI bounds, with 2-log inactivation from an LP UV dose occurring at $28.8 \mathrm{~mJ} / \mathrm{cm}^{2}$ and a LED/276 nm dose of $31.3 \mathrm{~mJ} / \mathrm{cm}^{2}$. It should be noted that the guidelines were developed for water with higher UVT values. Nevertheless, the enhanced sensitivity of MS2 in the septic tank effluent could be due to a number of factors, including sorption or aggregation of viral particles, oxidation from the additional dissolved organic matter, and challenges related to the particulate samples with very low UV transmittance $\left(\mathrm{UVT}_{254}<6 \%\right.$ ) values. For example, the higher concentration of suspended solids and particulate matter in the septic effluent provided a substrate for viral particle sorption as well as a photosensitizer for oxidation, both of which may have contributed to additional log reduction of MS2. In addition, maintaining complete sample homogeneity during UV absorbance measurements (in the cuvette), exposure (in the stirred Petri dish), and sample enumeration is challenging. For this reason, among others, UV disinfection studies with unfiltered water samples at $\mathrm{UVT}_{254}<10 \%$ are rare. 

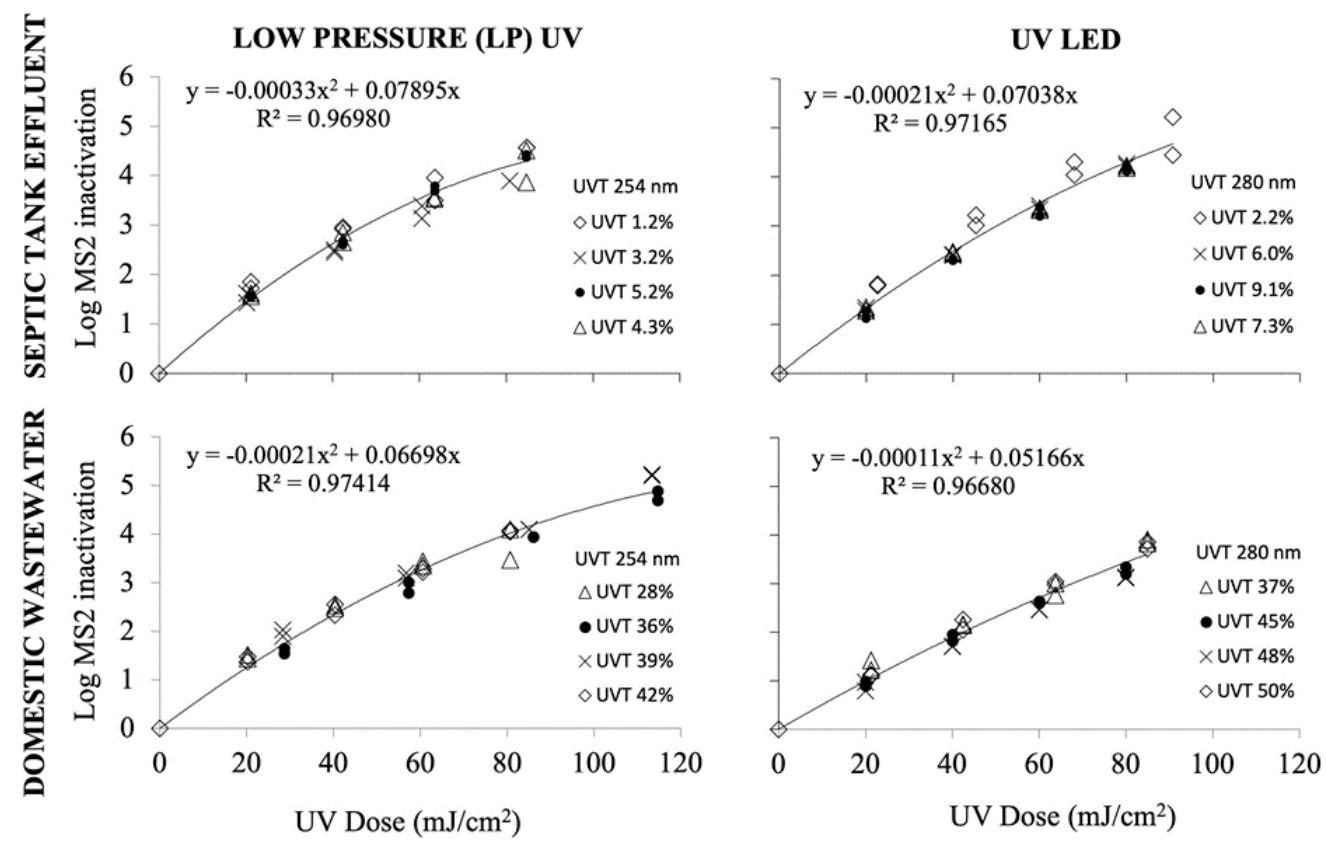

Figure 6. Dose response curves of MS2 bacteriophage in septic tank and domestic wastewater permeates. These collimated beam tests with the batch reactors were used to determine the UV dose in our flow-through reactors.

\subsection{Flow-Through UV Reactor Disinfection Efficiency}

For the LP UV flow-through reactor operating with wastewater and coffee at $\mathrm{UVT}_{254}$ values down to $37.8 \%$ and flow rates up to $1.5 \mathrm{~L} / \mathrm{min}$, all $10^{6}-10^{7} \mathrm{PFU} / \mathrm{mL}$ of MS2 were inactivated, indicating an applied dose of at least $140 \mathrm{~mJ} / \mathrm{cm}^{2}$. E. coli and total coliform at concentrations lower than $10^{4} \mathrm{CFU} / \mathrm{mL}$ were also completely inactivated in all $\mathrm{LP} \mathrm{UV}$ runs for domestic wastewater and septic effluent at flow rates as high as $1.8 \mathrm{~L} / \mathrm{min}$, which was the hydraulic limit for this reactor.

The model for LP UV inactivation of MS2 in septic tank effluent $\left(\mathrm{UVT}_{254}<5.2 \%\right)$ is given in the Supplementary Info (Figure S2); with a high agreement for predicted versus observed values of MS2 log inactivation as a function of flow rate (slope $=0.9999$, $\mathrm{R}^{2}=0.9999$ ). As shown in Table 3, an average RED of 48.8 to $50.8 \mathrm{~mJ} / \mathrm{cm}^{2}$ was achieved at flow rates of 1.8 and $1.5 \mathrm{~L} / \mathrm{min}$ for septic tank effluent. This dose was sufficient to completely inactivate E. coli and total coliforms remaining in the samples. Given the initial concentration of total coliforms $\left(3.3 \times 10^{5} \mathrm{CFU} / \mathrm{mL}\right)$ and their dose response to LP UV light, REDs at these flow rates were more than high enough to meet the WHO irrigation guidelines for fecal coliforms of $1000 \mathrm{CFU} / \mathrm{mL}$ for WFMF-treated wastewater $[29,37]$. Microorganisms of concern for septic tanks, for which outbreaks have been associated with poor septic tank performance, include norovirus, rotavirus, hepatitis A, Salmonella spp., and E. coli [58]. Table 3 estimates the LP UV log-inactivation of these pathogens from these doses given this MS2 RED. These RED were also high enough for inactivation of Giardia spp. and Cryptosporidium spp., which are not linked to septic tank discharge, but require only $22 \mathrm{~mJ} / \mathrm{cm}^{2}$ for 4-log reduction [37,58]. Similarly, an LP UV dose of $40-50 \mathrm{~mJ} / \mathrm{cm}^{2}$ would completely inactivate SARS-CoV-2, the virus responsible for COVID-19, which requires only $3.7 \mathrm{~mJ} / \mathrm{cm}^{2}$ for 3-log reduction in aqueous solutions. However, water and wastewater are not considered transmission pathways of this virus $[59,60]$. 
Table 3. Disinfection performance of flow-through LP UV inactivation of septic effluent $(n=4)$ for $\left(\mathrm{UVT}_{254}<5.2 \%\right)$. RED is the reduction equivalent dose determined from biodosimetry with the batch reactor.

\begin{tabular}{|c|c|c|c|c|c|c|c|}
\hline \multicolumn{4}{|c|}{ LP UV } & \multicolumn{4}{|c|}{ Estimated Inactivation Credit } \\
\hline $\begin{array}{l}\text { Flow Rate } \\
(\mathrm{mL} / \mathrm{min})\end{array}$ & $\begin{array}{c}\text { Exposure Time } \\
\text { (s) }\end{array}$ & $\begin{array}{c}\log \text { MS2 } \\
\text { Inactivation } \\
\left(\log _{10} \pm 1 \text { SD }\right)\end{array}$ & $\underset{\left(\mathrm{mJ} / \mathrm{cm}^{2}\right)}{\operatorname{RED}}$ & $\begin{array}{c}\text { Norovirus } \\
\quad\left(\log _{10}\right)\end{array}$ & $\begin{array}{l}\text { Rotavirus }^{2} \\
\left(\log _{10}\right)\end{array}$ & $\begin{array}{l}\text { Hepatitis A } \\
\quad\left(\log _{10}\right)\end{array}$ & $\begin{array}{c}\text { Salmonella }^{2} \\
\left(\log _{10}\right)\end{array}$ \\
\hline 1500 & 28 & $3.2 \pm 0.2$ & $50.8 \pm 3.8$ & 6.0 & $>4.1$ & $>5.4$ & $>5.6$ \\
\hline 1800 & 23 & $3.0 \pm 0.3$ & $48.8 \pm 7.9$ & 5.7 & $>4.1$ & $>5.4$ & $>5.6$ \\
\hline
\end{tabular}

The flow-through UV LED reactor, which had a lower irradiance than the LP UV reactor in this study, did not inactivate all MS2 bacteriophage in the spiked samples, as expected, which left more data for analysis. A model of the UV LED inactivation of MS2 bacteriophage as a function of flow rate and UVA-RLE for all water matrices tested was developed using a combined variable approach [47]. The modelled results are plotted along with the empirical data in Figure 7. Nonlinear regression was conducted to determine the coefficients of the mathematical model introduced in Equation (1), given below in Equation (2). The estimated coefficients for the UVC LED reactor were $\mathrm{a}=-0.38058$, $c=0.48857, d=-0.30841$, and $\mathrm{e}=0.09897$. Statistical significance $(p<0.05)$ was observed in coefficients a, c, d, and e; it was not observed in coefficient b. [47]. Statistical significance is not always reached for all coefficients of the combined variable approach; therefore, that term was removed $(b=0.0)$ as specified in the literature [47]. A close agreement was observed between the predicted and measured values (slope $=0.9889, \mathrm{R}^{2}=0.9889$, Figure 7), which indicates experimental repeatability across a wide range of UVT values.

$$
\log I=10^{-0.38058} \times\left(\frac{1}{Q}\right)^{0.48857-0.30841 \times U V A+0.09897 \times U V A^{2}}
$$

In comparison, Hull et al. [48] applied the combined variable approach for a UVC LED system challenged with MS2 bacteriophage in drinking water and obtained the following statistically significant $(p<0.05)$ coefficients: $a=-0.1952, b=-0.25607, c=0.65497$, $\mathrm{d}=-7.99858$, and e $=37.65489$. Differences between the calculated coefficients may be explained by the UVT ranges used for model validation as well as the reactor design. Hull et al. utilized drinking water matrices ranging from 74.6 to $99.4 \%$ UVT, while the current study used real and synthetic wastewater with UVTs spanning from 2.0 to $88.2 \%$. Regarding reactor design, the previous study used a spherical reactor with LEDs at one point source and a path length of up to $5.56 \mathrm{~cm}$, whereas the current study used a cylindrical UV LED reactor with UV LED arrays on four sides, forming a box around the cylinder with a maximum path length of $0.9 \mathrm{~cm}[25,48]$.

A plot of estimated RED versus flow rate for the UV LED flow-through reactor is given in the Supplementary Info (Figure S3). With the combined variable model given in Equation (3), we could estimate the RED for a given flow rate and water matrix. With this RED, we could then estimate the log reduction of enteric pathogens, including adenovirus, coxsackievirus, and poliovirus, for the UV LED flow-through reactor. Given the published dose response data of these organisms to UV LEDs with the same wavelength emission (peak $=276.6 \mathrm{~nm} ;$ FWHM $=9.8 \mathrm{~nm}$ ), using Equation (3) below, we could estimate the inactivation credits (Table 4) [43,62].

$$
R E D=10^{0.8716} \times\left(\frac{1}{Q}\right)^{0.4965-0.22554 \times U V A}
$$


Table 4. Disinfection performance for the flow-through UV LED reactor estimated from Equations (2) and (3) for wastewater and septic tank effluent. RED is the reduction equivalent dose estimated from the combined variable model for a given flow rate and UVT. RLE = relative lamp equivalent.

\begin{tabular}{|c|c|c|c|c|c|c|}
\hline \multicolumn{3}{|c|}{ UV LED } & \multicolumn{4}{|c|}{ Estimated Inactivation Credit } \\
\hline $\begin{array}{l}\text { Flow Rate } \\
\text { (mL/min) }\end{array}$ & $\begin{array}{l}\text { UVT-RLE } \\
\%\end{array}$ & $\begin{array}{l}\text { Estimated RED } \\
\qquad\left(\mathrm{mJ} / \mathrm{cm}^{2}\right)\end{array}$ & $\begin{array}{l}\text { MS2 } 1 \\
\left(\log _{10}\right)\end{array}$ & $\begin{array}{l}\text { Adenovirus }{ }^{2} \\
\quad\left(\log _{10}\right)\end{array}$ & $\begin{array}{c}\text { Coxsackievirus } \\
\left(\log _{10}\right)\end{array}$ & $\begin{array}{l}\text { Poliovirus } \\
\quad\left(\log _{10}\right)\end{array}$ \\
\hline 10 & 5 & 19.0 & 1.3 & 0.23 & $>4$ & $>4$ \\
\hline 10 & 30 & 42.5 & 2.1 & 0.80 & $>4$ & $>4$ \\
\hline 10 & 60 & 58.2 & 2.9 & 1.34 & $>4$ & $>4$ \\
\hline 10 & 90 & 69.8 & 3.7 & 1.83 & $>4$ & $>4$ \\
\hline 50 & 5 & 13.7 & 0.9 & 0.15 & 2.3 & 2.7 \\
\hline 50 & 30 & 23.1 & 1.2 & 0.31 & $>4$ & $>4$ \\
\hline 50 & 60 & 28.3 & 1.5 & 0.42 & $>4$ & $>4$ \\
\hline 50 & 90 & 31.9 & 1.7 & 0.51 & $>4$ & $>4$ \\
\hline
\end{tabular}

${ }^{1}$ This study, ${ }^{2}[43],{ }^{3}[62]$.

It is important to note that the UV LED reactor is scalable, and the combined variable approach allows us to estimate the log reduction for a reactor with the same configuration for a given UV LED output, flow rate, and UV absorbance. For example, doubling the relative lamp output (S/So) and doubling the flow rate, $Q$, would generate the same log inactivation of a test microorganism for water with the same UV absorbance [47].

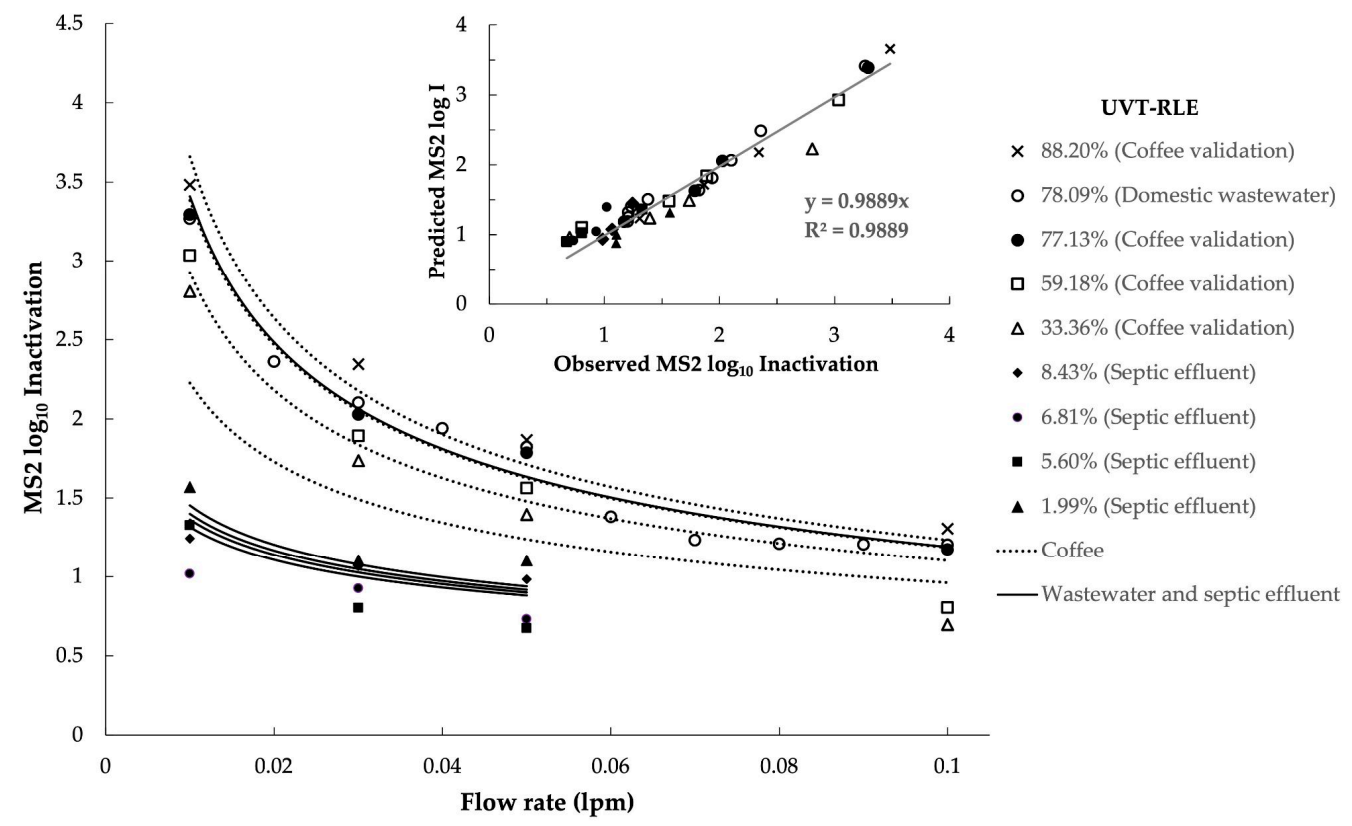

Figure 7. Measured (dots) and predicted (solid lines) MS2 log inactivation of MS2 coliphage as a function of the UV LED system flow rate and UVT-RLE. Values predicted using a combined variable approach Equation (2) as a function of UVA-RLE (presented as UVT-RLE) and flow rate with model coefficients $\mathrm{a}=-0.38058, \mathrm{~b}=0.0, \mathrm{c}=0.48857, \mathrm{~d}=-0.30841$, and $\mathrm{e}=0.09897$. Coefficients $\mathrm{a}, \mathrm{c}, \mathrm{d}$, and e were statistically significant $(p<0.05)$, whereas b was not. Inset: Predicted MS2 log inactivation versus observed MS2 log inactivation for the UV LED reactor $(276 \mathrm{~nm})$ for wastewater, septic tank effluent, and coffee validation. RLE = relative lamp emission; UVT = ultraviolet transmittance.

While other studies have modeled UV inactivation of viruses or viral surrogates in flow-through UV LED systems [63], this study was, to our knowledge, the first to apply combined variable monitoring for validation of a small-scale UV LED disinfection system 
used for wastewater treatment across a wide range of UVT values. This work showed that despite challenging and variable water quality conditions ( $2 \%<\mathrm{UVT}<88 \%)$, the disinfection was predictable across water types and flow rates. This approach enables us to optimize future reactor designs for broad applications.

WFMF is a low-cost filtration method, and UV LEDs have the major advantage of operating with low power consumption [16,20]. From a sustainability standpoint, this system could be further improved by operating both processes from remote or photovoltaic power sources, as has been done previously [64-66].

\section{Conclusions}

Global water demand requires increasing the use of reclaimed water, particularly for agriculture and irrigation to ease the burden on freshwater resources. However, reclaimed water poses health risks to users, and reuse must be done safely to protect public and environmental health. By making use of precious water and nutrient resources in a safe manner, wastewater reuse aligns with Sustainable Development Goal \#6: To Ensure Availability and Sustainable Management of Water and Sanitation for All.

This study developed and evaluated a decentralized wastewater treatment system with a small footprint and short operating time, combining physical and photochemical processes for treating wastewater at the source for potential reuse in agriculture. WFMF with UV LEDs can be used as a final polishing step for wastewater treatment systems. The research novelty is in incorporating UV disinfection into decentralized wastewater treatment processes, which has the environmental and economic benefit of avoiding chemical disinfection prior to irrigation and discharge, while protecting public health. UV LEDs enable a paradigm shift for water and wastewater treatment processes by offering treatment efficacy with innovative, robust, and compact designs [67]. This study is one of few to investigate UV LEDs for water reuse, as a proof of concept and performance as LEDs trend toward becoming a viable option for wastewater disinfection.

For domestic wastewater from a university campus, WFMF reduced TSS (by 79.8\%), turbidity (by 76.5\%), COD (by 38.5\%), BOD (by 47.8\%), and $\mathrm{NO}_{3}$ (by $41.4 \%$ ). UVT at $254 \mathrm{~nm}$ improved by $19.4 \%$, and UVT at $280 \mathrm{~nm}$ by $12.4 \%$. The treatment process met the Thailand irrigation standards for all parameters tested except BOD. For conventional septic tank effluent from a small community, WFMF did not meet Thailand irrigation standards, but it reduced TSS (by 77.9\%), COD (by 37.6\%), and TKN (by 13.5\%). For both wastewater sources, removal of microbial parameters, including total coliforms, E. coli, and MS2, was not statistically significant, requiring an additional disinfection step.

Following UV disinfection by LP UV and UV LEDs emitting at $276 \mathrm{~nm}$, wastewater quality met the WHO standards for unrestricted irrigation. Using biodosimetry with MS2 bacteriophage, the flow-through low-pressure UV system, manufactured on-site, achieved a very high reduction equivalent dose (RED), greater than $140 \mathrm{~mJ} / \mathrm{cm}^{2}$ for the wastewater effluent. For the septic tank effluent $\left(\mathrm{UVT}_{254}<5.2 \%\right)$, it achieved an RED of 50.8 and $48.8 \mathrm{~mJ} / \mathrm{cm}^{2}$ for flow rates of 1.5 and $1.8 \mathrm{~L} / \mathrm{min}$, respectively. The UV LED reactor, which was also manufactured on-site, achieved up to 3.5-log reduction of MS2 in wastewater at a low flow rate of $0.01 \mathrm{~L} / \mathrm{min}$; however, the system can be scaled up by incorporating more LED arrays. For UV LED inactivation of septic tank effluent, up to 1.5-log reduction of MS2 was attained. This study is one of few to apply combined variable monitoring for validation of a small-scale UV LED disinfection system, and one of the first to cover a broad range of water qualities. The combined variable approach is scalable, allowing us to estimate the log reduction for a reactor with the same configuration for a given UV output, flow rate, and UV absorbance. This work can be used to predict the performance of other wastewaters and help inform system design and application.

Supplementary Materials: The following are available online at https:/ / www.mdpi.com/article/1 0.3390/w13111564/s1, Figure S1: Irradiance surface profile of the UV LED batch reactor, Figure S2: Validation of predicted vs observed MS2 inactivation by the flow-through LP UV reactor in septic 
effluent, Figure S3: Measured (dots) and predicted (solid lines) RED as a function of the UV LED system flow rate and UVT-RLE.

Author Contributions: S.E.B. and T.K. acquired funding; S.E.B., P.S., T.R., T.K. conceived the experiments; P.S., T.R. and B.B. designed and conducted the experiments; P.S., T.R., T.M.H.N., V.A.H.-S., N.M.H. and S.E.B. analyzed the data. P.S., T.M.H.N., T.R., V.A.H.-S. and S.E.B. prepared the original manuscript draft. T.K. reviewed and edited the manuscript. All English-speaking authors have read and agreed to the published version of the manuscript.

Funding: The research: including equipment, supplies, and personnel, were supported by a grant from the Bill \& Melinda Gates Foundation in Seattle, Washington (grant OPP1029022). S. Beck was funded by the United States Department of State through a grant from the Fulbright Program (Fulbright ID 34143124). P. Suwan was supported financially by the Royal Thai Government (RTG) and Asian Institute of Technology (AIT) fellowships.

Institutional Review Board Statement: Not applicable.

Informed Consent Statement: Not applicable.

Data Availability Statement: Data available by contacting the corresponding author.

Acknowledgments: The authors thank the Naturally Acceptable and Technologically Sustainable (NATS) Staff for analyzing wastewater parameters and Panupong Boonyanun, senior technician in Environmental Engineering and Management Ambient Laboratory (AIT), for technical support in setting up the experimental system. We thank Chettiyappan Visvanathan for support with the woven-fiber textile and Traci Brooks for assistance with the combined variable modelling. We thank Pollawat Jamparuang at the National Institute of Metrology Thailand (NIMT) for conducting UV measurements and the Thailand Institute of Scientific and Technological Research (TISTR) for storing bacteria and virus stocks.

Conflicts of Interest: The authors declare no conflict of interest.

\section{References}

1. Burek, P.; Satoh, Y.; Fischer, G.; Kahil, M.; Scherzer, A.; Tramberend, S.; Nava, L.; Wada, Y.; Eisner, S.; Flörke, M. Water Futures and Solution-Fast Track Initiative; IIASA: Laxenburg, Austria, 2016.

2. IEA. Water Energy Nexus_Excerpt from the World Energy Outlook; IEA: Paris, France, 2016.

3. West, C.; Kenway, S.; Hassall, M.; Yuan, Z. Why do residential recycled water schemes fail? A comprehensive review of risk factors and impact on objectives. Water Res. 2016, 102, 271-281. [CrossRef] [PubMed]

4. WHO. Progress on Household Drinking Water, Sanitation and Hygiene 2000-2017: Special Focus on Inequalities; World Health Organization: Geneva, Switzerland, 2019.

5. Koottatep, T.; Chapagain, S.K.; Polprasert, C.; Panuvatvanich, A.; Ahn, K.-H. Sanitation situations in selected Southeast Asian countries and application of innovative technologies. Environ. Dev. Sustain. 2018, 20, 495-506. [CrossRef]

6. Simachaya, W. Wastewater tariffs in Thailand. Ocean Coast. Manag. 2009, 52, 378-382. [CrossRef]

7. Hutton, G.; Rodriguez, U.; Napitupulu, L.; Thang, P.; Kov, P. Economic Impacts of Sanitation in Southeast Asia: Summary. In World Bank Policy Research Working Paper; The World Bank: Washington, DC, USA, 2007; p. 44121.

8. Allen, A.S.; Borchardt, M.A.; Kieke, B.A.; Dunfield, K.E.; Parker, B.L. Virus occurrence in private and public wells in a fractured dolostone aquifer in Canada. Hydrogeol. J. 2017, 25, 1117-1136. [CrossRef]

9. Borchardt, M.A.; Bradbury, K.R.; Alexander, E.C., Jr.; Kolberg, R.J.; Alexander, S.C.; Archer, J.R.; Braatz, L.A.; Forest, B.M.; Green, J.A.; Spencer, S.K. Norovirus outbreak caused by a new septic system in a dolomite aquifer. Groundwater 2011, $49,85-97$. [CrossRef]

10. Polprasert, C.; Koottatep, T. Organic Waste Recycling: Technology, Management and Sustainability; IWA Publishing: London, UK, 2017.

11. Banda, L.J.; Mbewe, A.R.; Nzala, S.H.; Halwindi, H. Effect of siting boreholes and septic tanks on groundwater quality in St. Bonaventure township of Lusaka District, Zambia. Int. J. Environ. Sci. Toxicol. 2014, 2, 1-7.

12. Trimper, S. The Presence and Transport of Human Enteric Viruses in Fractured Bedrock Aquifers. Master's Thesis, Queen's University, Kingston, ON, Canada, 2010.

13. Ezugbe, E.O.; Rathilal, S. Membrane technologies in wastewater treatment: A review. Membranes 2020, 10, 89. [CrossRef]

14. Quist-Jensen, C.A.; Macedonio, F.; Drioli, E. Membrane technology for water production in agriculture: Desalination and wastewater reuse. Desalination 2015, 364, 17-32. [CrossRef]

15. Chollom, M.N.; Pikwa, K.; Rathilal, S.; Pillay, V.L. Fouling mitigation on a woven fibre microfiltration membrane for the treatment of raw water. S. Afr. J. Chem. Eng. 2017, 23, 1-9. [CrossRef] 
16. Alfa, D.; Rathilal, S.; Pillay, V.; Pikwa, K.; Chollom, M.N. Development and evaluation of a small scale water disinfection system. J. Water Sanit Hyg. Develop. 2016, 6, 389-400. [CrossRef]

17. Mecha, C.; Pillay, V.L. Development and evaluation of woven fabric microfiltration membranes impregnated with silver nanoparticles for potable water treatment. J. Membr. Sci. 2014, 458, 149-156. [CrossRef]

18. Cao Ngoc Dan, T.; Nguyen, T.T.; Bui, X.T.; Vo, T.D.H.; Truong, C.H.S.; Son, N.T.; Dao, T.S.; Pham, A.D.; Nguyen, T.L.C.; Nguyen, L.H. Low-cost spiral membrane for improving effluent quality of septic tank. Desalin. Water Treat. 2016, 57, 12409-12414. [CrossRef]

19. Khan, S.J.; Ali, S.; Visvanathan, C.; Pillay, V. Membrane fouling characterization in membrane-based septic tank. Desalin. Water Treat. 2013, 51, 6415-6419. [CrossRef]

20. Song, K.; Mohseni, M.; Taghipour, F. Application of ultraviolet light-emitting diodes (UV-LEDs) for water disinfection: A review. Water Res. 2016, 94, 341-349. [CrossRef]

21. Hijnen, W.; Beerendonk, E.; Medema, G.J. Inactivation credit of UV radiation for viruses, bacteria and protozoan (oo) cysts in water: A review. Water Res. 2006, 40, 3-22. [CrossRef]

22. Gibson, J.; Drake, J.; Karney, B. UV disinfection of wastewater and combined sewer overflows. In Ultraviolet Light in Human Health, Diseases and Environment; Springer: Berlin/Heidelberg, Germany, 2017; pp. 267-275.

23. Azaizeh, H.; Linden, K.; Barstow, C.; Kalbouneh, S.; Tellawi, A.; Albalawneh, A.; Gerchman, Y. Constructed wetlands combined with UV disinfection systems for removal of enteric pathogens and wastewater contaminants. Water Sci. Technol. 2013, 67, 651-657. [CrossRef]

24. Chevremont, A.-C.; Farnet, A.-M.; Coulomb, B.; Boudenne, J.-L. Effect of coupled UV-A and UV-C LEDs on both microbiological and chemical pollution of urban wastewaters. Sci. Total Environ. 2012, 426, 304-310. [CrossRef]

25. Nguyen, T.M.H.; Suwan, P.; Koottatep, T.; Beck, S.E. Application of a novel, continuous-feeding ultraviolet light emitting diode (UV-LED) system to disinfect domestic wastewater for discharge or agricultural reuse. Water Res. 2019, 153, 53-62. [CrossRef]

26. Vongsayalath, T. Development of Woven Fiber Microfiltration Membrane System for Water and Wastewater Treatment. Master's Thesis, Asian Institute of Technology, Pathum Thani, Thailand, 2015.

27. PCD. Effluent Standards: Standard of Discharging from Domestic Wastewater Treatment Plant in Thailand. Available online: https: / / www.pcd.go.th/ (accessed on 4 January 2021).

28. The Royal Irrigation Department. Royal Irrigation Department Order No.73/2554; The Royal Irrigation Department: Bangkok, Thailand, 2011.

29. WHO. A compendium of standards for wastewater reuse in the Eastern Mediterranean Region. In World Health Organization: Regional Office for the Eastern Mediterranean and Regional Center for Environmental Health Activities (CEHA); WHO: Geneva, Switzerland, 2006; Volume WHO-EM/CEH/142/E.

30. APHA. Standard Methods for the Examination of Water and Wastewater; American Water Works Association and Water Environment Federation: New York, NY, USA, 2012; Volume 22.

31. Moodley, P.; Archer, C.; Hawksworth, D.; Leibach, L. Standard Methods for the Recovery and Enumeration of Helminth Ova in Wastewater, Sludge, Compost and Urine-Diversion Waste in South Africa: Report to the Water Research Commission; Water Research Commission: Pretoria, South Africa, 2008.

32. Carré, E.; Pérot, J.; Jauzein, V.; Lopez-Ferber, M. Impact of suspended particles on UV disinfection of activated-sludge effluent with the aim of reclamation. J. Water Process. Eng. 2018, 22, 87-93. [CrossRef]

33. USEPA. Wastewater Technology Fact Sheet: Ultraviolet Disinfection; U.S Environmental Protection Agency: Washington, DC, USA, 1999.

34. Tchobanoglous, G. Wastewater Engineering: Treatment and Resource Recovery; McGraw-Hill: New York, NY, USA, 2014 ; Volume 2.

35. Beck, S.E.; Rodriguez, R.A.; Hawkins, M.A.; Hargy, T.M.; Larason, T.C.; Linden, K.G. Comparison of UV-induced inactivation and RNA damage in MS2 phage across the germicidal UV spectrum. Appl. Environ. Microbiol. 2016, 82, 1468-1474. [CrossRef]

36. Oguma, K.; Rattanakul, S.; Bolton, J.R. Application of UV Light-Emitting Diodes to adenovirus in water. J. Environ. Eng. 2016, 142, 04015082. [CrossRef]

37. USEPA. Ultraviolet Disinfection Guidance Manual for the Final Long Term 2 Enhanced Surface Water Treatment Rule: EPA 815-R-06-007; U.S. Environmental Protection Agency: Washington, DC, USA, 2006.

38. Sidhu, J.P.; Toze, S.G. Human pathogens and their indicators in biosolids: A literature review. Environ. Int. 2009, 35, 187-201. [CrossRef] [PubMed]

39. Amarasiri, M.; Kitajima, M.; Nguyen, T.H.; Okabe, S.; Sano, D. Bacteriophage removal efficiency as a validation and operational monitoring tool for virus reduction in wastewater reclamation. Water Res. 2017, 121, 258-269. [CrossRef] [PubMed]

40. Rattanakul, S.; Oguma, K. Inactivation kinetics and efficiencies of UV-LEDs against Pseudomonas aeruginosa, Legionella pneumophila, and surrogate microorganisms. Water Res. 2018, 130, 31-37. [CrossRef]

41. NWRI. Ultraviolet Disinfection Guidelines for Drinking Water and Water Reuse, 3rd ed.; National Water Research Institute: Fountain Valley, CA, USA, 2012.

42. USEPA. Method 1601: Male-Specific (F+) and Somatic Coliphage in Water by Two-Step Enrichment Procedure in EPA 821-R-01-030; U.S Environmental Protection Agency: Washington, DC, USA, 2001.

43. Beck, S.E.; Ryu, H.; Boczek, L.A.; Cashdollar, J.L.; Jeanis, K.M.; Rosenblum, J.S.; Lawal, O.R.; Linden, K.G. Evaluating UV-C LED disinfection performance and investigating potential dual-wavelength synergy. Water Res. 2017, 109, 207-216. [CrossRef] 
44. Kheyrandish, A.; Mohseni, M.; Taghipour, F. Protocol for Determining Ultraviolet Light Emitting Diode (UV-LED) Fluence for Microbial Inactivation Studies. Environ. Sci. Technol. 2018, 52, 7390-7398. [CrossRef]

45. Linden, K.L.; Wright, H.; Collins, J.; Cotton, C.; Beck, S. Guidance for Implementing Action Spectra Correction with Medium Pressure UV Disinfection; Water Research Foundation: Denver, CO, USA, 2015.

46. Erdal, U.G.; Awad, J.; Vorasis, M.; Wilder, M.; Moya, M. Evaluation of UV System Performance and Challenges of UV Validation Testing at the Laguna County Sanitation District; Water Environment Federation's Technical Exhibition and Conference: Dallas, TX, USA, 2006.

47. Wright, H.; Heath, M.; Brooks, T.; Adams, J. Innovative Approaches for Validation of Ultraviolet Disinfection Reactors for Drinking Water Systems; EPA: Washington, DC, USA, 2020.

48. Hull, N.M.; Herold, W.H.; Linden, K.G. UV LED water disinfection: Validation and small system demonstration study. AWWA Water Sci. 2019, 1, e1148. [CrossRef]

49. Tchobanoglous, G.; Burton, F.L.; Stensel, H.D. Metcalf E Eddy. Wastewater Engineering Treatment and Reuse, 4th ed.; Tchobanoglous, F.L., Burton, H., Stensel, D., Eds.; McGraw Hill: New Delhi, India, 2003; Volume 186.

50. Nam, N.H.; Visvanathan, C.; Jegatheesan, V. Performance Evaluation of Septic Tanks as Onsite Sanitation System; Southeast Water Environment 3; IWA Publishing: London, UK, 2009; pp. 141-146.

51. Koottatep, T.; Connelly, S.; Pussayanavin, T.; Khamyai, S.; Sangchun, W.; Sloan, W. 'Solar septic tank': Evaluation of innovative decentralized treatment of blackwater in developing countries. J. Water Sanit Hyg. Dev. 2020, 10, 828-840. [CrossRef]

52. Spychała, M.; Pawlak, M.; Nawrot, T. Capacity of textile filters for wastewater treatment at changeable wastewater level-A hydraulic model. Acta Sci. Pol. Form. Circumiectus 2016, 15, 421. [CrossRef]

53. USEPA. Guidelines for water reuse. In Special Restricted Crop Area; USEPA: Mendoza, Argentina, 2012.

54. Gullian, M.; Espinosa-Faller, F.J.; Núñez, A.; López-Barahona, N. Effect of turbidity on the ultraviolet disinfection performance in recirculating aquaculture systems with low water exchange. Aquac. Res. 2012, 43, 595-606. [CrossRef]

55. Martin, H.M. Studies on the Ascaris Lumbricoides. Doctoral Dissertation, University of Nebraska, Lincoln, NE, USA, 1926.

56. Tobias, A.; Bérubé, P.R. Contribution of biofilm layer to virus removal in gravity-driven membrane systems with passive fouling control. Separ. Purif. Technol. 2020, 251, 117336. [CrossRef]

57. Oguma, K.; Kita, R.; Sakai, H.; Murakami, M.; Takizawa, S. Application of UV light emitting diodes to batch and flow-through water disinfection systems. Desalination 2013, 328, 24-30. [CrossRef]

58. Adegoke, A.; Stenstrom, T. Septic Systems. In Global Water Pathogen Project; Rose, J.B., Jimenez-Cisneros, B., Eds.; Michigan State University: E. Lansing, MI, USA. Available online: http:/ / www.waterpathogens.org (accessed on 4 January 2021).

59. Bianco, A.; Biasin, M.; Pareschi, G.; Cavalleri, A.; Cavatorta, C.; Fenizia, F.; Galli, P.; Lessio, L.; Lualdi, M.; Redaelli, E. UV-C irradiation is highly effective in inactivating and inhibiting SARS-CoV-2 replication. Sci. Rep. 2021, 11, 1-7. [CrossRef]

60. Godini, H.; Hoseinzadeh, E.; Hossini, H. Water and wastewater as potential sources of SARS-CoV-2 transmission: A systematic review. Rev. Environ. Health 2021. published ahead of print. [CrossRef]

61. Rockey, N.; Young, S.; Kohn, T.; Pecson, B.; Wobus, C.E.; Raskin, L.; Wigginton, K.R. UV Disinfection of human norovirus: Evaluating infectivity using a genome-wide PCR-based approach. Environ. Sci. Technol. 2020, 54, 2851-2858. [CrossRef]

62. Woo, H.; Beck, S.E.; Boczek, L.; Carlson, K.M.; Brinkman, N.E.; Linden, K.G.; Lawal, O.R.; Hayes, S.L.; Ryu, H. Ecacy of Inactivation of Human Enteroviruses by Dual-Wavelength Germicidal Ultraviolet (UV-C) Light Emitting Diodes (LEDs). Water 2019, 11, 1131. [CrossRef]

63. Keshavarzfathy, M.; Hosoi, Y.; Oguma, K.; Taghipour, F. Experimental and computational evaluation of a flow-through UV-LED reactor for MS2 and adenovirus inactivation. Chem. Eng. J. 2021, 407, 127058. [CrossRef]

64. Lui, G.Y.; Roser, D.; Corkish, R.; Ashbolt, N.; Jagals, P.; Stuetz, R. Photovoltaic powered ultraviolet and visible light emitting diodes for sustainable point-of use disinfection of drinking waters. Sci. Total Environ. 2014, 493, 185-196. [CrossRef]

65. Li, B. A Sustainable, UV-LED Disinfection System for N95 masks in Haiti. Report. Available online: https://443.ece.illinois.edu/f iles/2020/05/COVIDReportLiWaterMarked.pdf (accessed on 18 May 2021).

66. Khine, P.P. A Comparative Study of Solar Mobile Membrane Drinking Water Treatment System and Point-of-Use Filter System. Master's Thesis, Asian Institute of Technology, Pathum Thani, Thailand, 2020.

67. Linden, K.G.; Hull, N.; Speight, V. Thinking Outside the Treatment Plant: UV for Water Distribution System Disinfection. Acc. Chem. Res. 2019, 52, 1226-1233. [CrossRef] 